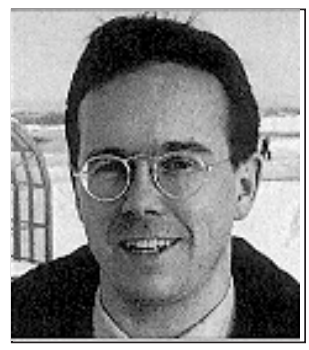

Juha Suoranta

\title{
Mediakulttuurin ja oppimisteknologioiden paradokseja
}

\author{
"Tietoyhteiskunta on sellainen tuhatkunta että se tietää \\ kaiken eikä ymmärrä mitään"' - Paavo Haavikko \\ "Eihän sillä loppujen lopuksi ole väliä, mistä \\ tuutista se mesitsi tulee" \\ - Jari Halosen elokuvasta Joulubileet
}

\begin{abstract}
Utopiat informaatio-, tieto-, kommunikaatioja oppimisyhteiskunnasta ovat viime vuosina johtaneet useisiin yhtäaikaisiin reaktioihin suomalaisyliopistoissa. Perinteisesti informaation, viestinnän ja median problematiikat ovat olleet tiedotusoppineiden heiniä. Nyttemmin akateemisia tieteenalarajoja ovat tulleet sekoittamaan kulttuurintutkimuksen monitieteiset, kysymyksenasetteluiltaan eklektiset lähestymistavat. Kiinnostuksen institutionalisoitumisesta kertoo jotain esimerkiksi Lapin yliopiston mediatiede-niminen oppiaine ja äskettäin täytetty mediakasvatuksen apulaisprofessuuri.
\end{abstract}

Tässä artikkelissa tarkastelen mediakulttuurille luonteenomaisia lupausten, lunastusten ja utopioiden paradokseja, joista rakentuvat $\mathrm{mm}$. oppimis- ja koulutusteknologioiden monisäikeiset ybteiskunnalliset kytkennät ja verkostot.

Kasvatustieteissäkään ei ole jääty odottelemaan. Lyhyellä aikaa on eripuolille maata perustettu uusia määräaikaisia ylempiä tutkimusja opetusvirkoja: uusien oppimisympäristöjen ja niiden teoreettis-metodologisten perusteiden apulaisprofessuuri Lapin yliopistoon, tiedotus- opin ja opettajankoulutuksen yhteinen mediakulttuurin ja viestintäkasvatuksen professuuri Tampereen yliopistoon ja mediakasvatuksen professuuri Helsingin yliopistoon. Edelläkävijä on ollut Joensuun yliopisto, jossa on toiminut vuodesta 1989 tietotekniikan opetuskäytön kehittämis- ja tutkimusyksikkö TOTY.

Koulutuspoliittisella kielellä sanottuna kysymys on vastaamisesta uuden tieto- ja oppimisyhteiskunnan asettamaan haasteeseen, mutta myös paljosta muusta. Ensinnäkin kysymys on hyvin konkreettisesti tutkimus- ja virkaresurssien allokoinnista kasvatustieteiden alueella.

Toiseksi kysymys on totuuden politiikasta foucaultlaisessa merkityksessä. Uudet virat ovat merkki uudesta tieteenalarajoja ylittävästä orientaatiosta suomalaisissa kasvatustieteissä. Enää maahamme tuskin perustetaan yhtään ainedidaktiikan ylempää virkaa. Institutionaalinen ratkaisu ei kuitenkaan kerro vielä mitään tutkimus- ja opetustoiminnan sisällöstä. Viroissa olevat tutkijat tulevatkin osaltaan määrittelemään sitä, mitä mediakulttuurilla, media- tai viestintäkasvatuksella ja uusilla oppimisympä- 
ristöillä tarkoitetaan, mitä kurssikirjoja luetaan, mihin teoriaperinteisiin kysymyksenasettelut sidotaan ja millaisista lähtökohdista tutkimusta tehdään ja ohjataan. (ks. viite 1 sivulla 257).

Tämä on tieteen- tai oppialan vakiinnuttamisen yleinen kaava: vallassa ja viroissa olevat legitimoivat sen mikä katsotaan tiedoksi ja mikä ei - olkoonkin, että määrittelykamppailuun kuuluu myötäsyntyisesti kritiikki. Kritiikki kuuluu kuitenkin niin perustavanlaatuisesti tiedonmuodostamisen moderneihin piirteisiin ja asiantuntijuuden määritelmään (ks. tästä Giddens 1995, 122), ettei se asiallisesti uhkaa itse legitimoinnin prosessia.

\section{Mediakulttuuri}

Oppimisteknologioiden alueella käsitteitä on runsaasti: toisaalla informaatio-, tieto-, kommunikaatio-, verkko- ja oppimisyhteiskunta, toisaalla verkko-, ja virtuaalioppiminen, -koulu ja -koulutus. Pyrin jäsentämään ajatteluani puhumalla mediakulttuurista, käyttämällä sitä alueen yleiskäsitteenä ja muita käsitteitä erityisemmissä yhteyksissä.

Mediakulttuurinkin käsite on laaja, ja sitä käytetään lukuisissa yhteyksissä. Viittaan mediakulttuurilla yleisesti omaan, tässä ja nyt elettävään aikaamme. Sen lisäksi, että sillä voidaan tarkoittaa yleistä kulttuurista tilannetta, se viittaa perinteisiin ja digitaalisiin viestintä- ja muihin välineisiin (Kellner 1995): olemme jo vuosikymmeniä olleet niiden ympäröimiä Kotiliedestä kännykkään, vinyylilevystä virtuaalikypärään. Lisäksi mediakulttuuri pitää sisällään ajatuksen keinotekoisesta yhteiskunnasta, jossa "kaikki todellisuuden ominaispiirteet ovat teknologioiden kehityksen myötä tulleet joko reaalisesti tai potentiaalisesti inhimillisen suunnittelun ja muuntelun piiriin" (Heiskala 1996, 182, ks. viite 2).

Keinotekoistuminen ei siis tarkoita vain sitä, että elämme tavaramaailmassa. Kirjaimellisesti koko todellisuus - fyysis-biologinen, tajunnallinen ja sosiaalinen - on keinotekoistunut: 1) keho on saanut tekoelimet ja elämää pidentävät lääk- keet, 2) tajunta rauhoittavat ja stimulanssinsa, terapiat ja koulutuksen, 3) sosiaalinen oleminen on jo määritelmänsäkin mukaisesti tehtyä ja 4) elinympäristö rakennettua ja suunniteltua.

Tämän lisäksi keinotekoinen viittaa ajatukseen todellisuuden välittyneisyydestä, jonka mukaan aktuaalinen katoaa virtuaaliseen: televisiotapahtuma samaistetaan todellisuuteen (Vattimo 1991, 24). Oppimisteknologiat osallistuvat osaltaan todellisuuden muunteluun ja simulointiin, siksi myös niitä sopii tarkastella keinotekoisuuden kannalta. Onhan jo tavanomaisuudessaan viaton oppikirjakin malli todellisuudesta.

Vaikuttaa siltä, että oppimisteknologiat ja ns. interaktiivinen opetus mallintavat usein vanhaa ohjelmoidun opetuksen kaavaa. On vaikea nähdä, miten koneen välityksellä simuloitu interaktiivisuus voi oppimisprosessina vastata tehokkuudeltaan esimerkiksi luovaa ja tapahtumahetkellä rakentuvaa luentoa. Uusien oppimisteknologioiden todellisista vaikutuksista ei juurikaan ole olemassa tutkimustietoa (Kanselaar 1996, 25).

\section{Mediakulttuurin paradokseja}

Mediakulttuurin hehkuheikit. Julkista puhetta mediakulttuurista luonnehtivat mahtailevat ennusteet mahdollisuuksien ja valintojen loputtomuudesta ja puolivillaiset teoretisoinnit ihmisten kaikinpuolisesta yhdenvertaisuudesta ja mahdollisuuksien tasa-arvosta. Digitaalisten viestintä- ja informaatioteknologioiden oppimissovellusten ja niiden kulttuuristen vaikutusten kentällä liikkuu tätä nykyä enemmän kuin missään muualla visionäärejä, konsultteja, profeettoja, ennustajia ja saarnaajia (ks. viite 3).

Mediakulttuurin toimijat ovat yleensä teknisen koulutuksen saaneita virtuaalitodellisuuden myyntitykkejä tai mediateknologisen herätyksen kokeneita entisiä humanisteja. Nykyisessä markkinatilanteessa on oltava ajanhermolla eikä ole harvinaista, että jokin teoreettinen esitys mediayhteiskunnasta tai postmodernismista tuotteistetaan ja tiivistetään iskulauseiksi, perustetaan konsulttibisnes, tehdään rahaa - 
kuka enemmän kuka vähemmän - ja vesitetään alkuperäinen idea.

Myyntimiehiä alkaa hiljakseen löytyä myös kasvatusoppineiden keskuudesta. Siksi on tärkeätä tunnistaa yleisimpiä mediakulttuurista ylläpidettyjä luuloja ja ymmärtää niiden paradoksaalinen luonne. Mediakulttuurissa mikään ei ole enää varmaa, ja kaikki on, Nietzschen (1967, 267) sanoin, "vain tulkintoja".

Kaksi verkkokulttuuria. Jälkiteollisista yhteiskunnista puhuttaessa on tullut tavaksi väittää design- ja muun pienimuotoisen täsmäteollisuuden nousevan keskeiseksi tuotantotekijäksi ja olevan sektori, josta löytyvät myös tulevaisuuden työpaikat. Viihde- ja informaatioteollisuudessa - jos ei muussakaan - asia ei kuitenkaan ole näin yksioikoinen.

Silicon Valleyn informaatioteollisuus on jakautunut kahteen maailmaan. Toisaalla ovat pienet mediapajat, jotka tuottavat runsaasti uusia informaatioteknologisia keksintöjä. Tuotteiden valmistus- ja markkinointikustannukset ovat kuitenkin niin suuret, että ideapajat eivät kykyne saattamaan prototuotteitaan massamittaisille kulutusmarkkinoille. Tämä on yksi syy siihen, miksi korporaatiot, mediajätit ja "verkkoparonit" voivat hyvin informaatioteollisuudessa. Teollisuuden ja markkinoiden kahtiajakautumisesta väitetään syntyvän myös kaksi erilaista verkkokulttuuria (Bronson \& Katz 1997, 29). Toinen on massojen, yritysten, suurten ohjelma- ja konemäärien kaupallinen bulkkikulttuuri. Tämän kulttuurin symbolina toimii jokakodin perusväline, televisio, jossa on www- ja sähköpostiyhteydet lähinnä viihdytys- ja kulutuskäyttöön. Tässä kulttuurissa on täysin mahdollista rakentaa koko elämäntapansa television varaan: koostaa identiteettinsä digitaalisen informaation perusteella, tehdä ruoka- ja muut ostokset televisiosta ja pitää yhteyksiä ulkomaailmaan sähköpostin välityksellä. Tähän kaupalliseen verkkokulttuuriin ihmisiä kannustetaan voimallisesti.

Toinen verkkokulttuuri rakentuu verkkonörttien ja alalle vihkiytyneiden ammattilaisten va- raan, jotka uskovat verkkojen demokraattiseen ja vapauttavaan käyttöön. Se pitää sisällään kaikenlaisen vaihtoehtokulttuurin, vihreät aatteet, vaihtoehtoisen informaatio- ja uutisvälityksen, vapaaehtoisen niukkuuden ja harmonisen elämän liikkeet. Tässä verkkokulttuurissa on ideoita, jotka pyrkivät vastaamaan markkinoistuneiden yhteiskuntien demokratiavajeeseen, toimimaan kansalaisten vapaina kommunikaatioväylinä ja sosiaalisesti merkittävinä muina (ks. termistä Suoranta 1997, luku 3). Vaihtoehtoisen verkkokulttuurin edustajat painottavat, ettei kansalaisvastarinta voi enää rakentua verkkokulttuurin ulkopuolella, vaan ulkopuolelle jääminen merkitsee auttamatonta syrjäytymistä yhteiskunnan (virtuaalisen) tapahtumisen ytimestä (ks. myös Sihvonen 1996, 68).

Valinnan vapaus. Potentiaalisesti tarjolla olevan informaation määrä on sähköisen informaatioteknologian vaikutuksesta lisääntynyt. Määrän lisääntyminen ei kuitenkaan kerro vielä mitään informaation saatavuudesta eikä ole riittävä ehto valinnan vapauksien lisääntymiselle.

Sen lisäksi, että valinnan vapauden kysymys on tunnettu filosofinen ikuisuusongelma, on se myös empiirinen ongelma sekä kommunikaation että aikuiskasvatuksen tutkimuksessa. Edellisen osalta ongelmaa valotti jo vuonna 1940 Paul K. Lazarsfeldin kumppaneineen tekemä tutkimus People's Choice poliittisesta mielipiteenmuodostuksesta ja äänestyskäyttäy-tymisestä. Havaittiin, että mediaviestit eivät menneet perille suoraan, vaan ns. mielipidejohtajien välityksellä. Mielipidejohtajat toimivat suodattimina ja tulkkeina siinä, miten viestit merkityksellistettiin (Lazarsfeld \& Merton 1960). Lisäksi huomattiin, että politiikan seuraaminen kasautui riippumatta mediasta. Kasautumisilmiöhän on tunnettu sekä yleisessä harrastuneisuudessa että aikuisopiskelussa ja koulutuspääomassa.

Malli on yhä käyttökelpoinen tekemään ymmärrettäväksi nykyistä mediakulttuuria. Mielipidejohtajuus on kuitenkin ehkä entistä enemmän siirtynyt medialle itselleen ja mainoksien hallitsemille, tarpeita luoville kulutusmarkkinoille. Nämä määrittelevät mitä on tieto ja totuus, 
ja osallistuvat merkittävällä tavalla "totuuden politiikkaan” (Foucault 1996). Ne määrittelevät mitä julkisesti pidetään tietona, mitä totuutena. Tutkimuksen kriittinen funktio ei tässä (postmodernissa) tilanteessa voi olla kuollut kirjain.

Aikuiskasvatuksen teoriassa ja käytännössä on puolestaan tunnettua, kaikista itseohjautuvuusteorioista huolimatta, etteivät kaikki aikuiset halua tai kykene opiskelemaan ja ohjautumaan elämässään itsenäisesti. Itseohjautuvuuden teoria kytkeytyy kiinteästi yksilöllisen valinnan vapauden ongelmaan ja sitä voidaan tässä yhteydessä nimenomaistaa viittaamalla ns. älyagentteihin. Keskustelussa oppimisteknologioiden valinnan vapauksia lisäävästä voimasta viitataan tietokoneisiin, tai niiden ominaisuuksiin, jotka keräävät, luokittelevat ja varastoivat informaatiota käyttäjän toiveiden mukaisesti. Älyagenttien käyttö ei kuitenkaan ole niin suoraviivaista kuin myyntipuhe antaa ymmärtää. Valinnan vapauden näennäisyys uuden teknologian käytössä käy ilmi siitä, että mielekkääseen käyttöön vaaditaan paljon esitietoja, kulttuurista pääomaa, uusia kommunikaatiotaitoja ja ennen kaikkea mielekäs tarkoitus, joka ei voi olla pelkkä aikansa kuluttaminen ja viheliäinen viihde maailmanverkossa.

Valinnan vapaus on länsimaiseen utopiaan kuuluva historiallisesti suhteellinen idea, joka on paradoksaalisessa suhteessa ihmiselle luontaisen yhteistunnon, yhteisyyden ja eriytymättömyyden haluun. Yksilön valinnan vapauksista ja itseohjautuvasta oppimisesta puhuttaessa unohtuu usein, että valinnat ovat vapaita vain tietyissä ennalta säädetyissä rajoissa ja itseohjautuvalla oppimisella on aina kulttuuriset ja sosiaaliset kehyksensä (Antikainen 1996, 265, 273), joskus sitä säätelevät yhteiskuntarakenteiden rautaiset kahleet.

Oppimisteknologiat ja valtautuminen. Uudet oppimis- ja viestintäteknologiat, erityisesti maailmanverkko, omaavat periaatteessa valtauttavaa voimaa. Niiden käyttöä on vaikea, ellei mahdoton, valvoa systemaattisesti tai paikantaa yksittäistä käyttäjää (viite 4). Ne näyttävät olevan sen modernin valtakäsityksen ulkopuolella, jota Michel Foucault kuvaa panoptisena.

Panoptismin periaatteen mukaan alamaiset ovat koko ajan tarkkailtavina. Tarkkailu merkitsee hallinnoimisen periaatetta, joka läpäisee läntisten valtioiden poliittisen historian 1400-luvulta tähän päivään. Foucault'n $(1980,71)$ mukaan vallankäytön alueella panoptismi oli yhtä merkittävä teknologinen keksintö kuin höyrykone materiaalisessa tuotannossa. Vallan panoptinen teknologia otettiin ensinnä käyttöön paikallisesti kouluissa, kasarmeissa ja sairaaloissa. Näistä tiloista kokonaisvaltaisen tarkkailun periaate yleistyi poliisin, keskushallinnon ja modernin valtion vallankäytön menetelmäksi.

Ei ole kuitenkaan varmaa, toimiiko panoptismin strategia verkostoituvissa ja virtualisoituvissa sosiaalisissa konteksteissa. Bauman (1996, 148) väittääkin, että jälkimoderneissa yhteiskunnissa panoptikonin on korvannut viettelevän vallan periaate. Ajatus on kiehtova tilanteessa, jossa koulutukselliset tilat täyttyvät mielihyväperiaatteen ohjaamalla virtuaalikulttuurilla: ennen muita pyrintöjä, kuten opinnollisuutta, pitää opetuksen ja oppimisen ennen kaikkea viihdyttää.

Myös demokratian kysymys asettuu viihdyttävässä mediakulttuurissa uuteen valoon. Informaatioekologian käsitteellä viitataan tutkimukseen, jossa tarkastellaan demokratian ehtojen toteutumisen edellytyksiä paisuvassa viestintätulvassa (Heiskala 1996, 214-218).

Voidaan tutkia sitä, miten viestit siirtyvät lähettäjän ja vastaanottajan välillä, millaisia mahdollisuuksia (informaation nopea siirrettävyys) ja esteitä (kommunikaatiotaidot ja -välineiden kustannukset) näihin siirtoihin sisältyy. Tarkastelu voidaan myös kohdistaa viestien frekvensseihin mediassa: asiat joista vaietaan, lakkaavat olemasta. Voidaan myös selvittää motivoituja hiljaisuuksia, ts. sitä, miten tietyt kysymykset jätetään tietoisesti keskustelun ulkopuolelle tai - välttääkseni salaliittoteoretisointia - ne joutuvat sinne sosiaalisen toiminnan suunnittelemattomasta kenttärakenteesta johtuen. 
Tarkkailla ja rangaista. Vaikka maailmanverkko omaakin mediakulttuurin keskeisenä ilmiönä valtauttavaa potentiaalia, mahdollistaa uusi digitaaliteknologia ihmisten toiminnan entistä tarkemman valvonnan. Televisio on tehokas valvonnan väline. Suosittu saippuaooppera alkuillasta vastaa tuhatta poliisia. Kadunvarsien valvontakameroiden ja maata kiertävien sateliittien linssit voidaan tarkentaa tallentamaan yksittäisen ihmisen toiminnan pieninkin yksityiskohta. Jättämiämme digitaalisia jälkiä voidaan seurata luotto- ja pankkikorteista, erilaisista tiedostoista, rekistereistä ja älykorteista. Kulkuri ja lentojätkä eivät kuulu informaatioyhteiskuntaan. Mark Poster (1990, 93) viittaa Foucault'iin puhuessaan elektronisen teknologian mahdollistamista tarkkailujärjestelmistä superpanoptikonina, johon tallentuu osa arkipäivämme historiaa.

Perinteisessä mediassa uuteen mediaan liitetään herkästi myös erilaisia äärimmäisyyksiä. Sosiaalisista epäluomista ollaan herkästi syyttämässä uusia informaatio- ja viihdytysvälineitä, ennen kaikkea maailmanverkkoa, kun aikaisemmin syypää löytyi televisiosta. Maailmanverkko antaakin huolestuneille paljon taivasteltavaa, onhan se todellinen Babelin torni, jossa uusnatsit, pedofiilit, hardcore ja lastenlorut esiintyvät rinnatusten aidon demokratian hengessä.

Virtuaalipornojupakat ja joukkoitsemurhat korvaavat uutismelskeessä kriittisen tai edes analyyttisen tarkastelun. Baudrillardin (1991, 13) termein todellisuudesta on tullut rivoa, kun elämä on joutunut informaation ja kommunikaation alituisesti potentiaaliseen valokeilaan:

"Informaatiosta ja kommunikaatiosta, virtapiireistä ja verkostoista sekä toiminnoista ja objekteista tulee yhtä pornografiaa. Rivous ei ole enää kätkettyä, torjuttua tai hämärää vaan näkyvää, liian näkyvää, näkyvämpääkin näkyvämpää. Rivous merkitsee salaisuuden menettämistä, informaatioon ja kommunikaatioon kokonaan liukenemista."
Mediakulttuuri ja sukupuolten yhdenvertaisuus. Maailmanverkkoa (WWW) myydään kaikille avoimena informaatioväylänä. Teknisesti se toimii monisuuntaisesti ilman keskustaa ja mahdollistaa nopean ja rajoittamattoman vuorovaikutuksen ja informaationvälityksen. Ehkä siksi siitä on myös tullut suosittu koulutuspoliittinen puheenaihe kaikissa 1. maailman maissa (viite 5). Mediakulttuurin pyhässä allianssissa on kolme osapuolta: poliittinen eliitti, mediateknologiabisnes ja tutkijat, jotka pyrkivät hyötymään poliittisista suhdanteista, liike-elämän satsauksesta tai molemmissa (viite 6).

Poliittis-taloudellis-tutkimuksellisista intresseistä nousevat kannanotot korostavat informaatioteknologian yhdenvertaistavaa merkitystä ja antavat mahdollisuuden tarkastella asian toista puolta, kysymystä mediakulttuurin eriarvoistavista ja polarisoivista käytännöistä (viite 7). Mediakulttuurin tasa- ja eriarvoisuuden tärkeimmät rajat kulkevat sukupuolen, kulttuurija taloudellisen pääoman, iän ja asuinpaikan mukaan. Vaikka ne kaikki ovat tärkeitä (aikuis)kasvatustieteellisen kulttuurintutkimuksen kohteita, tässä artikkelissa ne on jätettävä viitteen (viite 8) varaan ja tarkasteltava lähemmin vain ensin mainittua.

Tutkimukset koulujen käytännöistä, yritysmaailmasta ja verkkobisneksestä toistavat saman havainnon: mediakulttuuri on vinoutunut sukupuolisesti. Aluetta hallitsevat miehet ja miehiset toimintatavat. Miehet myös kirjoittavat uusista viestintäteknologioista ja mediakulttuurista (viite 9):

"One of the problems with the computer society is that not only is it an almost all-male society, but it's a little-boy society, part of an ongoing infantilization of the society over the past half century" (Brockman 1997).

Naisten kiinnostuksen lisäämisessä ja lisääntymisessä virtuaalimaailmaan on kaksi puolta. Toisaalta esimerkiksi Dale Spender (1995, 168), joka kehittelee kirjassaan virtuaalisen sisaruuden (virtual sisterhood) ajatusta, sanoo uuden median hallinnan olevan jatkossa joka(na)isen 
perustaito. Naiset eivät voi jäädä tässä suhteessa lukutaidottomiksi, "informaatioköyhiksi", tietokoneista kieltäytyminen ei enää kuulu vastarinnan välineisiin.

Toisaalta tyttöjen ja naisten saamisella medianpauloihin on kysymys voittojen maksimoinnista, puhtaasta liiketoiminnasta: miten kasvattaa kaikista - sukupuoleen katsomatta - mediakuluttajia?

Virtuaalitodellisuudesta ja oppimisteknologioista kirjoittavat naistutkijat ovat tärkeällä tavalla tuoneet esiin näkökulman, jonka mukaan oppimisteknologioissa ei missään merkityksellisessä mielessä ole kysymys teknologioista. Kysymys on kokonaan uudesta historiallisesta tilanteesta, jossa määritellään alusta asti niin todellisuus, yhteiskunta ja ihmisen paikka kuin sukupuolten sosiaaliset ja lihalliset järjestykset. Ehkä ei ole mitään ihmettelemistä siinä, ettei tietokonepelikulttuuri löydä helposti paikkaansa tyttökulttuurissa, sillä sovellukset ovat militaristista alkuperää, syntyneet aseteknologisesta tutkimuksesta. Esimerkiksi nykyisillä maastotaisteluvälineillä tai ilmataisteluteknologialla ei ole suurta eroa video- ja virtuaalipelien todellisuuksiin. Näiden ja pelien ero on siinä, että edelliset ovat tarkoitettu tappamaan, jälkimmäiset viihdyttämään. Ryhtymättä sensoriksi voi kysyä, millaiseen todellisuuteen tällaiset virtuaalipelit opettavat, kun muistetaan väite aktuaalisen katoamisesta virtuaaliseen? Onko eron katoamisella vaikutusta myös moraalitajuun? Mediatajun kasvattamisen yksi olennainen puoli on epäilemättä yrittää selvittää toden ja toden tunnun välistä yhä häilyvämpää eroa.

Uudet oppimisteknologiat korvaavat entiset opetuskäytännöt. Kirjakulttuurin yleistyessä 1400-luvun puolivälin jälkeen pelättiin yleisesti, että retoriikka, oraalinen kulttuuri ja rajattua kirjallista kulttuuria hallinneen kirkon mahti tulevat kirjanpainamisen yleistymisen myötä häviämään. Tietokonekulttuurissa on käynyt samoin: on pelätty digitaalisen kulttuurin hävittävän kirjat ja viisauden.
Suullinen perinne ei kuitenkaan ole kadonnut kirjojen myötä, eivätkä kirjat ja paperituotteet virtualisoituvasta maailmasta. On käynyt pikemminkin päinvastoin: Desktop publishing on lisännyt kirjankustannustoimintaa ja kirjallisuus elää myös digitaalisesti. Niin kauan kuin joku haluaa nauttia lukemisesta muuallakin kuin näyttöpäätteen äärellä, ottaa kirjan mukaansa aurinkoiselle hiekkarannalle tai vaikka vessaan, ei kirjallisella kulttuurilla ole hätää.

Normaalin koulutuksen tulevaisuudesta on myös esitetty kysymyksiä. On kysytty, katoavatko oppimisen perinteiset muodot, kasvokkainen opetus, kirjojen lukeminen ja opiskelu kokeineen ja tentteineen ajattomaan ja paikattomaan (viite 10) virtuaalitodellisuuden kolmanteen, kokonaan keinotekoiseen luontoon. Miten puuta ja betonia oleville koululaitoksille käy virtuaalikoulujen tullessa arkipäiväksi? Näyttää selvältä, että tulevaisuudessa oppimis-, opetus- ja opiskelukäytännöt avautuvat niin kuin kirjojen aikakaudella elänyt Nietzsche (1996, 353) ennusti:

"Now that self-education and fraternal education are becoming more general, the teacher must, in the form he now normally assumes, become almost redundant. Friends anxious to learn who want to acquire knowledge of something together can find in our age of books a shorter and more natural way than 'school' and 'teacher' are."

Formaalikoulutus on toiminut modernin edistyksen moottorina. Se on luonut postraditionaalisen sosiaalisen järjestyksen ja koulinut ihmisistä hyvällä hyötysuhteella työkuntoisia demokratian alamaisia. Informaatio- ja oppimisteknologiat sinänsä eivät tee perinteistä koulutusta tarpeettomaksi tai muuta sen käytäntöjä. Kysymys voi olla vain yleisemmistä sosiaalisista muutospaineista - edistyksen harhojen paljastumisesta, massamuotoisesta työttömyydestä, kansallisvaltioiden häviämisestä -, jotka pakottavat koulutusorganisaatiot korjaamaan kurssiaan. Teknologiat voivat kylläkin olla apuvälineitä siirryttäessä oppimisen monimuotoisiin konteksteihin. 
Nykyisin kasvatustieteessä kirjoitetaan paljon oppimisympäristöistä. Diskurssit voi jakaa paljonkaan asiaa pelkistämättä kahtia. Toisaalta puhutaan siitä, että koulujen opetus- ja oppimiskäytäntöjen tulisi muuttua vastaamaan ympäröivän yhteiskunnan toimintoja, simuloida ja mallintaa "todellisen elämän" oppimisympäristöjä. Toisaalta tutkimuksessa keskitytään empiirisesti ja teoreettisesti koulun ulkopuolisiin oppimisyhteyksiin. Aittola ym. (1995, 33) ovat äskettäin esittäneet havainnon siitä, että “oppiminen on liukumassa virallisten kasvatusinstituutioiden ulkopuoliseen maailmaan." $\mathrm{Ha}$ vaintoa on kiinnostavaa verrata Oiva Kyöstiön (1956, 241) neljän vuosikymmenen takaiseen:

"Entisten dominoivien kasvatustekijöiden, kirkon, koulun ja kodin rinnalle on syntynyt uusia voimia, jotka olennaisesti vaikuttavat lapsen kehitykseen. Nuo voimat eivät vaikuta vain kodin ja koulun ulkopuolisina tekijöinä, vaan ovat tunkeutuneet usein olennaisesti niiden sisäiseen toimintapiiriin. Lehdistön, radion, filmin ja television merkitys nykyaikaisina massaopetusvälineinä ja yleisinä mielipiteen muokkaajina on suorastaan musertavan suuri."

\section{Miten kasvatustiede vastaa?}

Kasvatustieteellinen tutkimus on orientoitunut mediakulttuurin tutkimukseen yleensä kahdella tavalla. Joko teoreettiseksi viitekehykseksi on otettu uudempi, yleensä konstruktivistinen oppimisen psykologia (esim. Pantzar 1995, Kanselaar 1996) tai teknologinen soveltamistutkimus (esim. Tella 1996, Kari ym. 1997). Seurauksena tästä on ollut, että oppimisteknologiat ovat jääneet sitomatta yhteiskunnallis-historiallisiin puitteisiinsa puhumattakaan, että niitä olisi kysytty filosofisesti esimrerkiksi Martin Heideggerin (1994) viitoittamaa tietä (viite 11). Teknologis-psykologinen lähestymistapa oppimisteknologioiden kasvatustieteellisessä tutkimuksessa näyttääkin toistavan kasvatustieteiden yhteiskunnallisen kontekstittomuuden siirryttäessä didaktiikkauskosta uusien oppimisympäristöjen kaikkivoipaisuuteen (Simola 1996, 33, ks. viite 12).
Mediakulttuurin kasvatuksellisessa käsitteellistämisessä tarvitaankin uutta perusymmärrystä kasvatustieteen ja pedagogiikan luonteesta. Erään ehdotuksen on tehnyt Henry Giroux (1992, 3) määrittelemällä pedagogiikan kulttuurisen ja poliittisen tietoisuuden tuottamisen muodoksi, joka on "kietoutunut tietojen, halujen ja sosiaalisten käytäntöjen rakentamiseen ja organisoimiseen. Kysymys on sellaisen pedagogiikka-käsityksen kehittämisestä, jonka avulla symbolisen tuotannon hallitsevat muodot voidaan riitauttaa."

Arkipäivää ja oppimista hallitsevien symbolisten muotojen riitauttamiseen, kritiikkiin tai edes kyseenalaistamiseen psykologian, didaktiikan tai teknologian näkökulmat ovat riittämättömiä. Tarvitaan kasvatustieteellistä kulttuurintutkimusta (esimerkiksi Giroux ym. 1996), jota pidän edellisiä kiinnostavampana lähestymistapana ymmärtää - empiirisesti ja teoreettisesti mediakulttuurin ilmiöitä ja merkityksiä, vaikka lähestymistavat voikin nähdä komplementaarisena (viite 13).

Yleisesti sanoen kasvatustieteellisen kulttuurintutkimuksen tebtävänä on tarkastella toisaalta sitä, miten teknologisesti välittyvä kulttuurinen kokemus muovaa jälkimoderneja subjekteja ja toisaalta kuinka vallan käytänteet toimivat mediakulttuurin erilaisissa merkitystiloissa (ks. tästä Poster 1990, 16; Sibvonen 1996, 50).

\section{Kritiikki poiskytkennän periaatteena}

Kysymys vallan muodoista ja ihmisten hallinnoimisen tavoista muodostui 14 . ja 15 . vuosisadalla sivilisoituneen ihmiskunnan ratkaisua vaativaksi kysymykseksi. Hallinnoimisen (governmentality) periaatteen vastinpariksi syntyi kritiikin idea: ilman tietoisuutta subjektiudesta, alamaisuuden merkityksessä, ei kritiikkiäkään tarvittu. Kritiikki syntyi kolmesta lähteestä: kysymyksenä raamatullisten tekstien oikeasta tulkinnasta, oikeudesta kohtuun ja tieteen auktoriteetin kysymisenä. (Foucault 1996, 384385.) 
Kritiikki edellytti lähtökohdissaan kysymysten esittämistä. Kriittisen kysymyksen yleinen muoto oli ja on: miten voimme olla vähemmän hallinnoituja, vähemmän alamaisia? Mediakulttuurin kasvatuksellisia merkityksiä kysyttäessä kysymys on muotoa: miten voimme olla vähemmän medioiden armoilla ja enemmän tietoisia valinnoistamme ja siitä, mitä niillä teemme? Tässä erityisessä mielessä kritiikissä on kysymys mediatajun (Sihvonen 1996, 24), mediatietoisuuden, medialukutaidon (vrt. toiminnallinen lukutaito) tai yksinkertaisesti median käyttötaidon syntymisestä ja synnyttämisestä.

Tämän kirjoituksen kontekstissa mediakritiikistä voi puhua poiskytkennän periaatteena. Vasta poiskytkennän periaate on kriittisesti koetellun toiminnan kestävä perustelu. Periaate sanoo, että jos toiminta tai toiminnan väline oppimisteknologiat ja niiden käyttö - havaitaan merkityksettömäksi sivistyksellisten tai demokraattisten tavoitteiden kannalta, pitää tästä seurata toiminnan arviointi ja uudelleen suuntaaminen. Jotta toiminta olisi perusteltua ja merkityksellistä, on lisäksi oltava ei vain kuvainnollinen vaan myös kirjaimellinen mahdollisuus lähteä pois, sammuttaa näytöt ja kuvaruudut, vetää töpselit irti seinistä.

\section{Iatret}

AITTOLA, T., ERÄMIES, T., JAUHIAINEN, J., JOKI, H., LAINPELTO, V., PARTANEN, R. \& TIKKANEN, J. (1995) "Koulua käydään tulevaisuutta varten, vapaaajasta nautitaan nyt." Nuorisotutkimus 13 (3), 33-44.

ANTIKAINEN, A. (1996) Merkittävät oppimiskokemukset ja valtautuminen. Teoksessa Antikainen, A. \& Huotelin, H. (toim.) Oppiminen ja elämänhistoria. Jyväskylä: BTJ Kirjastopalvelu, 251-296.

BAUDRILLARD, J. (1991) Ekstaasi ja rivous. Suom. T. Arppe. Helsinki: Gaudeamus

BAUMAN, Z. (1996) Postmodernin lumo. Suom. J. Vainonen. Tampere: Vastapaino.

BROCKMAN, J. (1996) Inter-Not. Why cyberspace is an empty place. Utne Reader (http://www.utne.com/lens/ $\mathrm{mt} / 19 \mathrm{mtinternot} \cdot \mathrm{html})$

BRONSON, P. \& KATZ, J. (1997) Why William Bennett is a blockhead, how much techies hate Bill Gates, and what "old media" journalists haven't figured out yet? At Random 6 (1), 27-31.

FEENBERG, A. \& HANNAY, A. (toim.) (1995) Technology \& the politics of knowledge. Bloomington \& Indianapo- lis: Indiana University Press.

FOUCAUlT, M. (1980) Power/knowledge. Tr. C. Gordon, L. Marshall, J. Mepham \& K. Soper. New York: Pantheon Books.

FOUCAULT, M. (1996) What is critique? Teoksessa Schmidt, J. (toim.) What is enlightenment? Tr. K. P. Geiman. Berkeley: University of California Press, 382-398.

GIDDENS, A. (1995) Elämää jälkitraditionaalisessa yhteiskunnassa. Teoksessa Beck, U., Giddens, A. \& Lash, S. Nykyajan jäljillä. Suom. L. Lehto. Jyväskylä: Vastapaino, 83-152.

GIROUX, H. (1992) Border crossings. New York \& London: Routledge.

GIROUX, H., LANKSHEAR, C., McLAREN, P. \& PETERS, M. (1996) Counternarratives. New York \& London: Routledge.

HARAWAY, D. (1996) Modest_wittness@second_millenium. New York \& London: Routledge.

HEIDEGGER, M. (1994) Tekniikan kysyminen. Suom. V. Jaaksi. Niin \& näin 1 (2), 31-40.

HEISKALA, R. (1996) Kohti keinotekoista yhteiskuntaa. Tampere: Gaudeamus.

KANSELAAR, G. (1996) Lifelong learning, with and without new media. LLinE 1 (1), 18-25.

KARI, J., ISOMÄKI, H., MARTTUNEN, M., PIRHONEN, A. \& SUOMALA, J. (1997) UCRET tarjoaa oppimisen näkökulmaa tietotekniikan käyttöön ja kehittämiseen. Kasvatus 28 (1), 181-190.

KELLNER, D. (1995) Media culture, London \& New York: Routledge

KROHN, L. (1996) Kynä ja kone. Porvoo: WSOY.

KYÖSTIÖ, O. K. (1956) Kasvatuksen uusinta tutkimusta Keski-Euroopassa II. Kasvatus ja koulu 42, 231-246.

LAZARSFELD, P. F. \& MERTON, R.K. (1960) Mass communication, popular taste and organized social action. Teoksessa Schramm, W. (toim.) Mass communications. Urbana, Chicago, London: University of Illinois Press, 492-512.

LEHTONEN, M. (1996) Merkitysten maailma. Tampere: Vastapaino.

NIETZSCHE, F. (1967) The will to power. Tr. W. Kaufmann \& R. J. Hollingdale. New York: Vintage Books.

NIETZSCHE, F. (1996) Human, all too buman. Tr. R. J. Hollingdale. Cambridge: Cambridge University Press

PANTZAR, E. (1995) Theoretical views on changing learning environments. Teoksessa Pantzar, E., Pohjolainen, S., Ruokamo-Saari, H. \& Viteli, J. (toim.) Theoretical foundations and applications of modern learning environments. Tampereen yliopiston tietokonekeskus \& hypermedialaboratorio. Tampereen yliopisto, 85-101.

POSTER, M. (1990) The mode of information. Cambridge: Polity Press.

POSTMAN, N. (1996) The end of education. New York: Vintage Books.

SIHVONEN, J. (1996) Aineeton syli. Tampere: Gaudeamus.

SIMOLA, H. (1996) Pedagoginen kontekstualismi ja opettajankoulutuksen opetussuunnitelmat. Kasvatus 28 (1), 24-37.

SINCLAIR, C. (1996) Net chick. A smart-girl quide to the wired world. New York: Henry Holt \& Co.

SPENDER, D. (1995) Nattering on the net. North Mel- 
bourne: Spinifex Press.

STONE, A. (1996) The war of desire and technology at the close of the mechanical age. Cambridge, Mass. \& London: The MIT Press.

SUORANTA, J. (1997) Kasvatuksellisesti näkeväksi. Tampere: Taju.

TELLA, S. (1996) Mediakasvatus ja kasvatustieteen uudet haasteet. Yliopisto 44 (19).

VATTIMO, G. (1989) Läpinäkyvä ybteiskunta. Suom. J. Vähämäki. Helsinki: Gaudeamus.

\section{Vittes}

1. Valtakunnan virallisena instanssina toimii tietoyhteiskuntaneuvottelukunta.

2. Keinotekoinen ei tässä yhteydessä tarkoita vähemmän todellista. Keinotekoinen yhteiskunta on aivan yhtä todellinen kuin esitraditionaalinen, traditionaalinen tai moderni. Sen sijaan keinotekoisen yhteiskunnan käsitteeseen saattaa olla kirjoitettuna marxahtava ajatus vieraannuttavasta ja esineistävästä yhteiskunnasta, ts. idea ja kaipaus alkuperäisyyteen.

3. Dan Steinbock (Yliopisto nro 18, ss. 22-26) on pelkistänyt mediakulttuurin positiot nelikentäksi, joka perustuu toisaalta erottelulle yksityiseen ja julkiseen sektoriin, toisaalta liberaaliin ja konservatiiviseen poliittiseen näkemykseen:

$\begin{array}{lll}\text { Yksityinen } & \begin{array}{l}\text { Konservatismi } \\ \text { "Kovat optimistit" }\end{array} & \begin{array}{l}\text { Liberalismi } \\ \text { "Idealistiset } \\ \text { uneksijat" } \\ \text { Julkinen }\end{array} \text { "Kovat realistit" } \\ \text { "Pebmeät } \\ \text { buolebtijat" }\end{array}$

4. Internetin synty on kylmän sodan aikakaudessa. Se kehitettiin ydinasesodan paikattomaksi komentojärjestelmäksi. Jos Pentagon olisi räjäytetty, joku jolla olisi ollut mikrotietokone ja modeemiyhteys vaikka Arizonan autiomaassa, olisi voinut laukaista vapaan maailman vastaiskun minne tahansa maapalloa.

5. Yhdysvalloissa Bill Clinton vaatii jokaiselle 12-vuotiaalle internet-yhteyttä, meillä ministeri Olli-Pekka Heinonen ja pääjohtaja Jukka Sarjala ajavat jokaiseen kouluun käyttöliittymiä vuoteen 2000 mennessä.

6. Apple Magazine-lehden (2/97, s. 14) teksti voisi yhtä hyvin olla opetusministerin puheesta kuin verkkopedagogiikkaa koskevasta tutkimussuunnitelmasta: "Varsinainen kimmoke Maten luomiseen oli idea 'jaetusta opiskeluympäristöstä' tai 'opiskelemisesta milloin ja missä vain'. Tästä on vauhdilla tulossa Yhdysvaltojen, Iso-Britannian ja muiden Euroopan maiden opetusviranomaisten tavoite."

7. Asia on huomattu myös opetusministeriössä. Opettajalehden (11.4.1997) haastattelussa Hannele Koivunen myöntää tietoyhteiskunnan polarisoivan ihmisiä ja puhuu telede- mokratian puolesta.

8. Kulttuuripääoman merkitys tasa-arvopolitiikan näkökulmasta: millainen merkitys mediakulttuurilla on luokka-asemasta riippuen? Onko se pelkkää viheliäistä mukavuutta vai tietoista kulutusta? Taloudellisen pääoman merkitys: kenellä on varaa nauttia median monimuotoisista hedelmistä? Ikä: kenellä on vaadittavat kommunikaatio- ja kielitaidot kriittiseen kansalaisuuteen virtuaaliyhteiskunnassa? Asuinpaikka: mitkä ovat digitaalisten informaatio- ja viestintäteknologioiden vapauttavat muodot ja erot mediakulutuksessa erityisesti 1. maailman ja muiden maailmoiden välillä?

9. Poikkeuksia ovat esimerkiksi Dale Spender (1995), Donna Haraway (1996), Leena Krohn (1996), Clara Sinclair (1996), Allucquére Stone (1996). Mediakulttuurista miesten ja miehisenä maailmana antaa kuvan Vanity Fair-lehden (1996, nro 434) vuosittainen Top 50-lista informaatioajan establismentista. Bill Gatesin, Ted Turnerin, Robert Murdochin ja muiden joukkoon oli laskettu kaksi naista.

10. Neil Postmanilla $(1996,42-43)$ on antaa opiskelun ajattomuuden ja paikattomuuden hakemista hauskoja esimerkkejä. Amerikkalaisille oppimisteknologiauskovaisille, jotka kertovat vetoavasti pikku Eevasta, joka ei saa unta, ja menee sitten näyttöpäätteelle opiskelemaan algebraa, Postman vastaa: "Little Eva's problem is not how to get access to a well-structured algebra lesson, but what to do with all the information available to her during the day, as well as during sleepless nights. Perhaps this is why she couldn't sleep in the first place."

11. Teknologian filosofiassa Heidegger on runsaasti viitattu ja analysoitu filosofi. Esimerkiksi äskettäisessä teknologian ja tiedon politiikan suhteita käsittelevässä kokoelmassa (Feenberg \& Hannay 1995) Heideggerin tekniikan filosofialle on omistettu oma osastonsa.

12. Tyypillisiä yhteiskunnan sulkeistavia lausumia ovat esimerkiksi: "Tietoyhteiskunnassa on keskeistä tapa, jolla ihminen prosessoi informaatiota" ja "Oppiminen ymmärretään nykyään tapahtumaksi, jossa ihminen tuottaa itse aktiivisesti tietoa" (Kari ym. 1997, 181). Kulttuurintutkijan kysymys kuuluu: Onko tietoyhteiskunnassa muutakin keskeistä kuin tiedon prosessoinnin yksilölliset tavat? Kuka tietoa jakaa, markkinoi ja tuottaa? Kuka määrittelee mikä on tietoa? Kuka omistaa tietoa? Edellä mainitut lausumat ovat vasta analyysin lähtökohtia.

13. Esimerkiksi uusien oppimisympäristöjen, joilla tässä yhteydessä tarkoitan viestintäräjähdyksen jälkeisen digitaalisen informaatioteknologian oppimissovellutuksia, tutkimukseen ja käsittämiseen on olemassa kaksi suhteellisen vastakkaista mahdollisuutta. Toisaalta oppimisen psykologian, erityisesti konstruktivismin, ja havainnon tutkimuksen näkökulma, toisaalta kulttuurintutkimuksen, ts. mediakulttuurin sosiaalisten merkitysten tutkimuksen ja kritiikin, näkökul$\mathrm{ma}$.

Artikkeli sa a pui 10.5.1997. Se hyväksyttiin julka istavaksi toimituskunnan kokouksessa 4.6.1997. 